\begin{tabular}{|l|l|l|l|l|l|}
\hline J. Tek. Ling & Vol. 13 & No. 1 & Hal. 47 - 58 & Jakarta, Januari 2012 & ISSN 1441-318X \\
\hline
\end{tabular}

\title{
KERAGAAN MODEL BUDIDAYA PERIKANAN TERINTEGRASI MULTI TROPIK DI PANTAI UTARA KARAWANG, JAWA BARAT
}

\author{
Ratu Siti Aliah \\ Peneliti di Pusat Teknologi Produksi Pertanian \\ Deputi Bidang Teknologi Agroindustri dan Bioteknologi BPPT \\ Gd. II BPPT, JL. M.H. Thamrin No.8, Jakarta 10340 \\ ratusitialiah@yahoo.com
}

\begin{abstract}
Abstrak
Teknologi budidaya perikanan terintegrasi multi tropik IMTA (Integrated Multi Tropic Aquaculture) dengan menggunakan ikan nila, udang, rumput laut dan kerang yang dipelihara dalam satu kolam telah menunjukkan produktivitas yang tinggi dan stabilitas lingkungan yang cukup baik dibandingkan dengan yang monokultur. Demikian halnya denga budidaya yang sejenis walau tidak menggunakan kerang, telah memberikan produktivitas dan kualitas air yang lebih baik. Namun demikian kualits tanah juga berpengaruh besar terhadap keberhasilan budidaya terutama untuk komoditas udang windu yang hidup di dasar. Nilai potensial redox yang negatif dapat menjadi tanda buruknya kualitas tanah untuk budidaya dan perlu di rehabilitasi. Untuk tanah seperti ini nampaknya ikan nila dan rumput laut menjadi alternatif komoditas yang cukup baik untuk dikembangkan, karena pertumbuhannya tidak terganggu.
\end{abstract}

kata kunci : Keragaan Model Budidaya Perikanan Terintegrasi Multitropik, Pantai Utara Karawang

\begin{abstract}
Integrated Multi Tropic Aquaculture (IMTA) technology by using tilapia, shrimp, seaweed and shellfish that are cultured in one pond integrately have demonstrated high productivity and environmental stability compared to the monoculture. Similarly, cultivation of similar model with unusing a shell has been providing productivity and better water quality. However, soil quality also greatly affect on the success of farming, especially for commodity shrimp that live on the benthic. Negative redox potential value can be a sign as a poor quality of land for cultivation and needs to be rehabilitation. For this kind of soil, cultivation of tilapia and seaweed as alternative commodities is excellent to be developed, because their growth is not disturbed.
\end{abstract}

key words : Performance of the Integrated Multi Tropic Aquaculture (IMTA) Model in the northern coastal area of Karawang, West Java 


\section{PENDAHULUAN}

\subsection{Latar Belakang}

Indonesia memiliki lahan tambak 1,2 juta ha, namun baru $37,5 \%$ nya yang dimanfaatkan untuk kegiatan budidaya perikanan. Masih rendahnya tingkat pemanfaatan ini umumnya disebabkan oleh terjadinya kerusakan lingkungan akibat ekploitasi berlebihan dalam pemanfaatan lahan tambak secara intensif pada periode tahun 1980-an. Untuk mengatasi penurunan produksi dan rendahnya tingkat pemanfaatan lahan tambak ini perlu dicarikan terobosan (inovasi) teknologi budidaya perikanan yang ramah lingkungan, produktif dan berkelanjutan (sustainable). Melalui Pengembangan Model Teknologi Budidaya Terintegrasi "Integrated Multi-rophic Aquaculture (IMTA)" Hemat Air di lahan tambak, dengan menerapkan teknologi ini, diharapkan produktivitas lahan tambak dapat meningkat baik di tingkat lokal, regional bahkan nasional.

Teknologi Budidaya Perikanan "Integrated Multi-Trophic Aquaculture (IMTA)" merupakan teknologi bersih (green technology) berwawasan lingkungan karena teknologinya bersifat Zero Emition atau bebas limbah ${ }^{1,2,3}$ ). Dengan teknologi IMTA produktivitas lahan tambak dapat ditingkatkan persatuan luasnya (ha) melalui pengembangan usaha budidaya perikanan secara terintegrasi dan intensif dari ikan nila unggul, udang windu, rumput laut Glacilaria $s p$. dan kekerangan yang dipelihara dalam suatu ekosistem yang kondisi kualitas lingkungan perairannya terjaga dengan baik. Dalam sistem ini, limbah organik sisa pakan dari ikan atau udang akan di manfaatkan oleh kekerangan, sementara rumput laut akan memanfaatkan perairannya yang kaya akan nutrien untuk pertumbuhannya sehingga tercipta keseimbangan ekosistem ${ }^{4,5,6,7,8,9,10,11)}$. Dengan demikian produktivitas dari spesimen yang dibudidayakan secara terintegrasi dapat tumbuh dan berkembang secara optimal dan efisien dalam pemanfaatan sumberdaya perairan yang tersedia. Teknologi budidaya perikanan terintegrasi IMTA apabila berhasil diterapkan secara massal di lahan tambak ditingkat nasional, maka pendapatan masyarakat, daerah dan perekonomian negara secara keseluruhan akan meningkat. Untuk mengetahui keragaan model budidaya perikanan terintegrasi multi tropik, telah dilakukan uji coba dengan menggunakan 4 (empat) perlakuan berbeda dan 4 jenis komoditas perikanan, yaitu ikan nila, udang, rumput laut dan kerang hijau.

\subsection{Tujuan}

Tujuan dari penelitian ini adalah untuk mengetahui keragaan model budidaya perikanan terintegrasi multi tropik untuk meningkatkan produktivitas lahan tambak marjinal yang terbengkalai (idle) di wilayah pesisir.

\subsection{Waktu dan Tempat Penelitian}

Lokasi penelitian di lahan tambak milik Balai Pengembangan Budidaya Air Payau dan Laut (BPAPL) Karawang, Jawa Barat (Gambar 1), selama 4 bulan dari bulan AprilJuli 2010.

\section{METODA PENELITIAN}

Tahapan kegiatan penelitian model budidaya perikanan terintegrasi multi tropik atau "Integrated Multi Tropical Aquaculture (IMTA)" dimulai dengan membuat desain perkolaman, sistem pengairan dan pemilihan jenis komoditas yang dibudidayakan. Desain kolam ditata dengan menggunakan penataan sistem pengairan semi tertutup dimana air yang mengalir berasal dari saluran pemasukan luar sebagai sumber air utama dan air buangan dari kolam. Air yang masuk ke kolam produksi baik dari sumber luar maupun buangan dari kolam, kualitas airnya sudah dalam keadaan baik dan layak digunakan untuk kegiatan penelitian. 


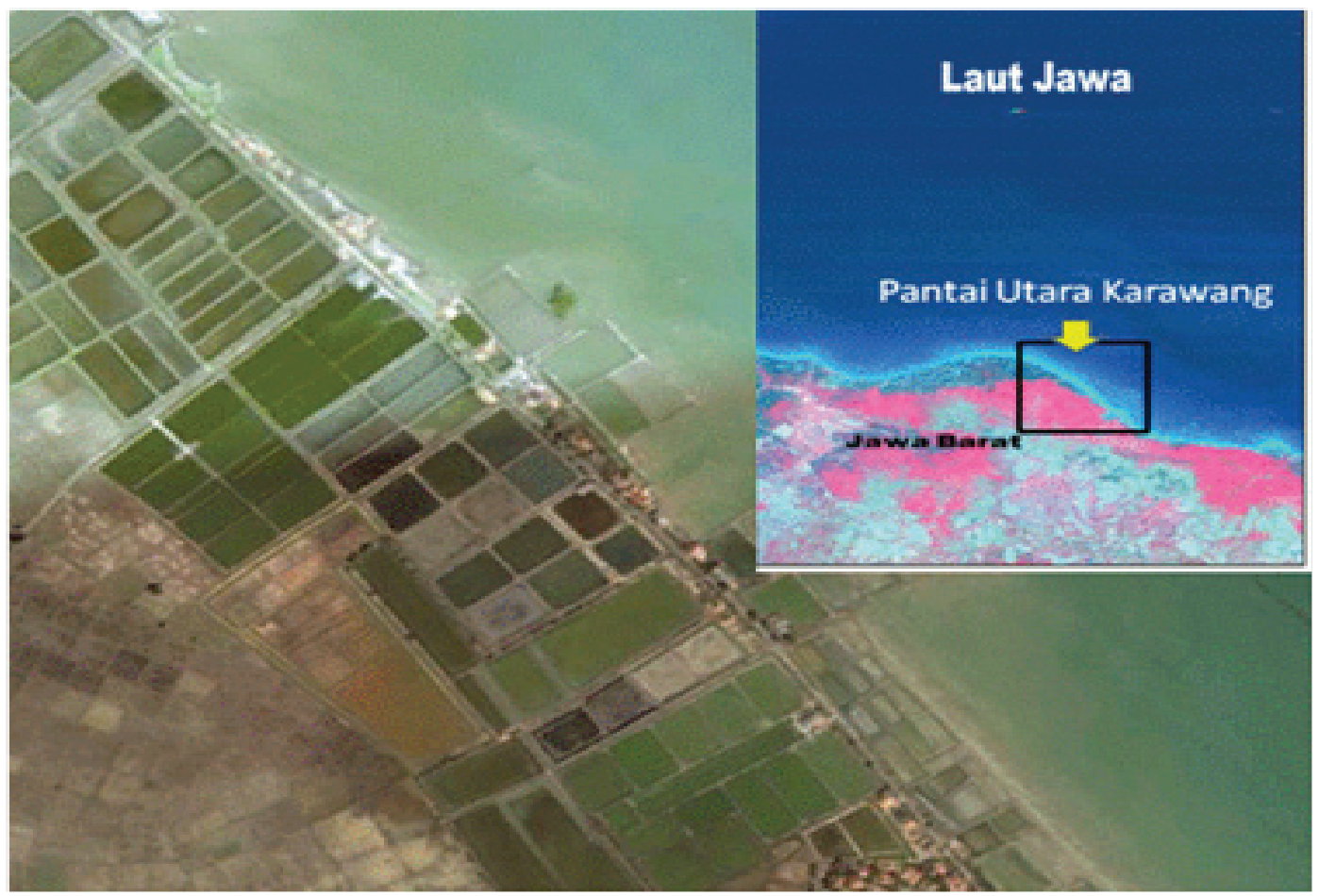

Gambar 1. Lokasi Penelitian Model Budidaya Perikanan Terintegrasi Multi Tropik "Integrated Multi Tropical Aquaculture (IMTA)" Karawang, Jawa Barat

Air dari sumber utama, sebelumnya telah mengalami pengolahan baik secara fisik melalui pengendapan maupun secara biologis (treatment algae dan kekerangan). Sedangkan air buangan kolam produksi, selain kualitas airnya masih cukup baik, stabil dan layak digunakan kembali, untuk meningkatkan kualitasnya di treatment baik secara fisik (pengendapan) maupun secara biologis (algae dan kekerangan) sebelum dimasukkan kembali ke saluran pemasukkan. Penggantian air sebanyak $30 \%$ akan dilakukan 3 hari sekali. Kolam penelitian didesain berukuran kurang lebih $500 \mathrm{~m}^{2}$ yang terdiri dari 12 kolam ditambah kolam treatment air/tandon. Dengan sistem ini, penggunaan air di lahan tambak diharapkan bisa dihemat. Desain kolam, saluran pembuangan, saluran air dan penataan kolam tambak sesuai pedoman Juknis Best Management Practise (BMP) Budidaya Perikanan di Iahan Tambak
(Gambar 2) dari Ditjen Perikanan Budidaya (2007).

Tahap selanjutnya adalah pemilihan komoditas perikanan yang dibudidayakan. Pemilihan komoditas perikanan tidak hanya didasarkan kepada pertimbangan nilai ekonomi semata, tetapi juga didasarkan kepada pertimbangan fungsi ekologis dan peranannya dalam menjaga stabilitas kesehatan lingkungan perairan kolam. Pertimbangan ini dimaksudkan selain untuk meningkatkan produksi dan nilai tambah dari tambak, juga untuk menjaga agar kegiatan usaha budidaya perikanan berkelanjutan (sustainable) dan kondisi lingkungan serta ekosistem perairannya tetap terjaga dengan baik dan lestari.

Berdasarkan pertimbangan tersebut, maka komoditas yang digunakan dalam penelitian keragaan model budidaya perikanan terintegrasi multi tropik atau "Integrated Multi Tropical Aquaculture 


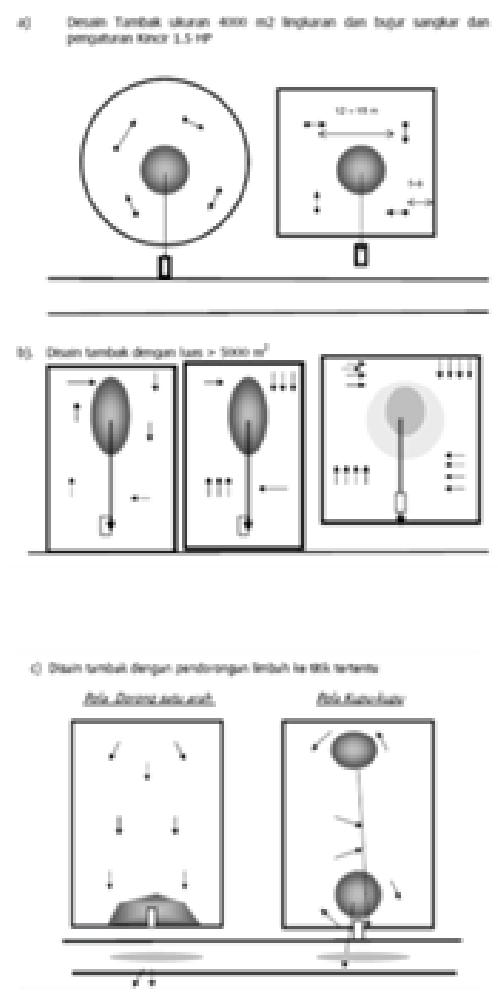

A
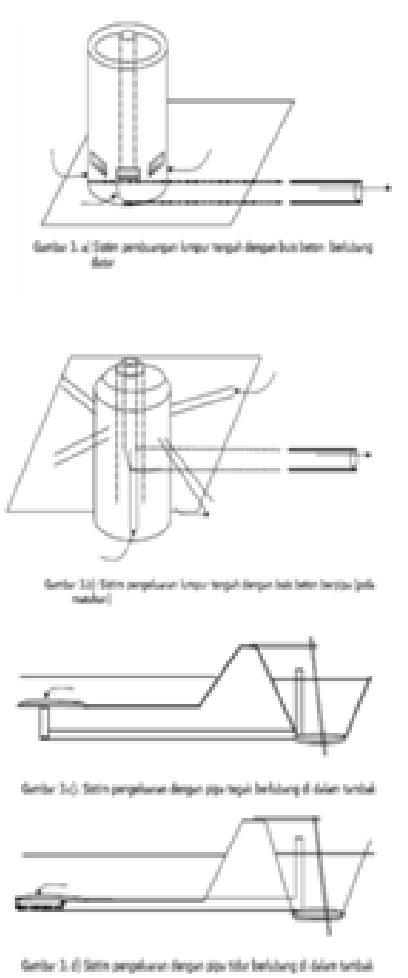

B
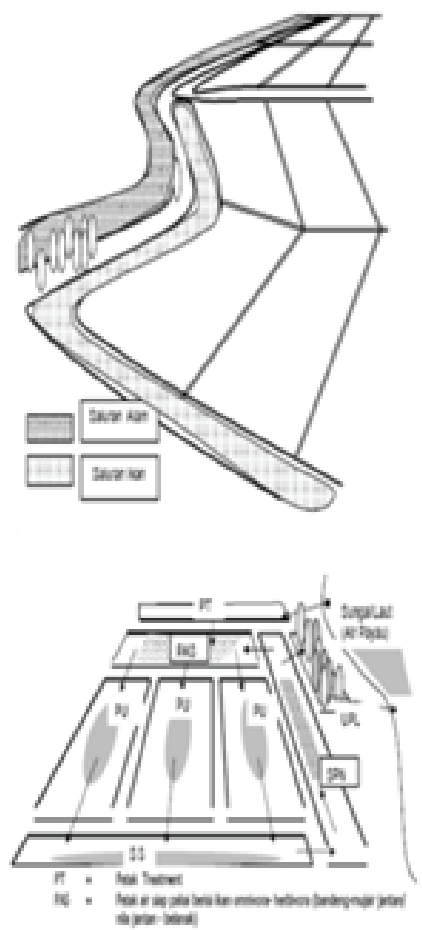

C

Gambar 2. Desain kolam (A),saluran pembuangan (B) dan penataan kolam (C) sesuai dengan Juknis Best Management Practise (BMP) Budidaya Perikanan di lahan tambak Penelitian Model Budidaya Perikanan Terintegrasi Multi Tropik "Integrated Multi Tropical Aquaculture (IMTA)" Karawang, Jawa Barat

(IMTA)" adalah ikan nila unggul monosek jantan, udang windu (Penaeus monodon), rumput laut Glacilaria dan kekerangan (kerang hijau=Perna viridis). Dalam sistem ini, kondisi dan kualitas perairan diharapkan dapat terjaga stabilitasnya dengan baik, karena limbah organik sisa pakan dari ikan atau udang akan di manfaatkan oleh kekerangan, sementara rumput laut akan memanfaatkan perairannya yang kaya akan nutrien untuk pertumbuhannya sehingga tercipta keseimbangan ekosistem. Dengan demikian produktivitas dari specimen yang dibudidayakan secara terintegrasi dapat tumbuh dan berkembang secara optimal dan efisien dalam pemanfaatan sumberdaya perairan yang tersedia. Berdasarkan pertimbangan ekonomi, ke-empat komoditas perikanan yang dibudidayakan merupakan komoditas ekonomi penting unggulan pemerintah.

Dalam penelitian keragaan model budidaya perikanan terintegrasi multi tropik atau "Integrated Multi Tropical Aquaculture (IMTA)" di lahan tambak. Benih ikan nila ukuran 10-12 $\mathrm{cm}$ ditebar dengan padat penebaran $5 \mathrm{ekor} / \mathrm{m}^{2}$, benur udang windu 5 ekor/m2, rumput laut dengan sistem longline $0,1 \mathrm{~kg} / \mathrm{m} 2$, atau $100-150 \mathrm{gr} / \mathrm{titik}$ dan kekerangan disebar di dasar kolam, dimasukkan kedalam keranjang atau sistem longline. Desain kolam penelitan dan model budidaya perikanan terintegrasi multi tropik atau "Integrated Multi Tropical Aquaculture (IMTA)" seperti terlihat pada Gambar 3 di desain berdasarkan 4 perlakuan dengan 
3 kali ulangan. Perlakuan 1 (P-1), berisi udang windu (1 komoditas), P-2 berisi ikan nila dan udang windu (2 komoditas), P-3 berisi ikan nila, udang windu dan rumput laut (3 komoditas) dan P-4 berisi ikan nila, udang windu, rumput laut dan kerang hijau (4 komoditas).

\subsection{Pemantauan Keragaan Pertumbuhan Komoditas Budidaya}

Untuk mengetahui keragaan pertumbuhan komoditas yang dibudidayakan dalam setiap perlakuan kolam percobaan, dilakukan pemantauan dengan mengukur pertumbuhannya. Demikian halnya dengan kualitas air baik fisika (temperatur, salinitas, $\mathrm{pH}$, kekeruhan, oksigen terlarut atau DO) maupun kimia (ammonia, nitrat dan fosfat) dipantau secara teratur setiap bulan untuk mengetahui stabilitas kondisi lingkungan perairan.

\section{HASIL DAN PEMBAHASAN}

INLET (Rumput Laut dan Kekerangan)
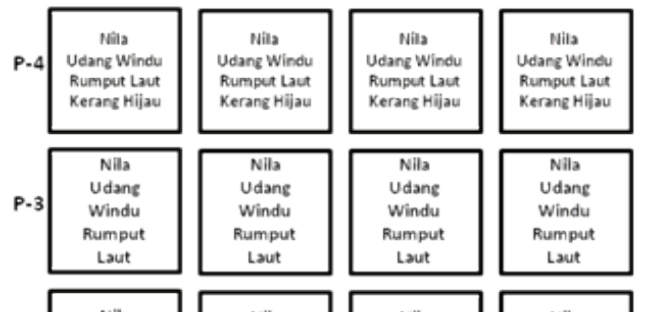

$500 \mathrm{~m}^{2}$
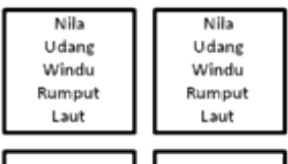

Kerang Hijau
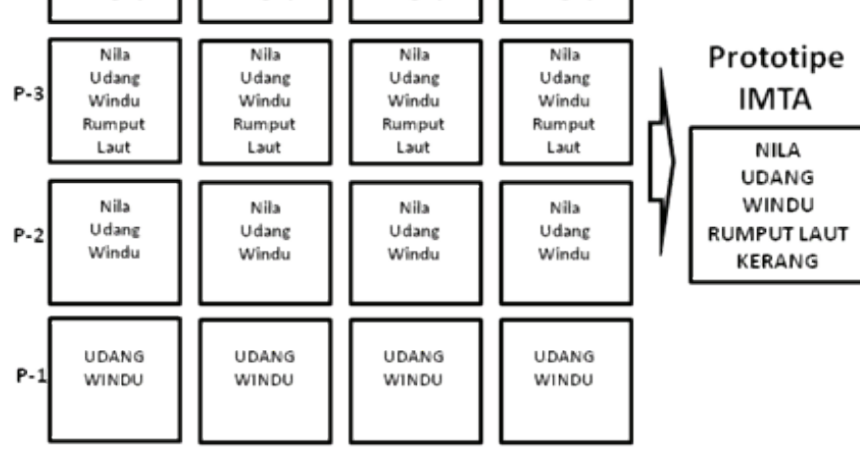

outlet (Rumput Laut dan Kekerangan)

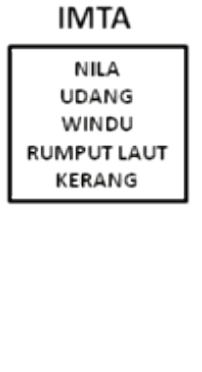

Untuk mengetahui keragaan pertumbuhan komoditas yang dibudidayakan dalam setiap perlakuan Model Budidaya Perikanan Terintegrasi Integrated MultiThropic Aquaculture (IMTA) telah didesain model kolam uji coba dengan ukuran 500 $\mathrm{m} 2$ sebanyak 12 kolam. Dari ke 12 kolam tersebut, telah dibagi masing-masing menjadi 3 kolam yang berisi udang windu (Penaeus monodon) sebagai kontrol, 3 kolam berisi udang windu (Penaeus monodon) dan ikan nila monosex jantan, 3 kolam berisi udang windu (Penaeus monodon), ikan nila monosex jantan dan rumput laut (Gracillaria) serta 3 kolam berisi udang windu (Penaeus monodon), ikan nila monosex jantan, rumput laut (Gracillaria) dan kerang hijau (Perna viridis). Untuk itu selama kegiatan dipantau kinerja masing-masing model budidaya baik dari segi pertumbuhan komoditasnya, produktivitas, maupun stabilitas ekosistem perairannya yang didasarkan kepada hasil pemantauan kualitas air secara teratur sesuai jadwal.

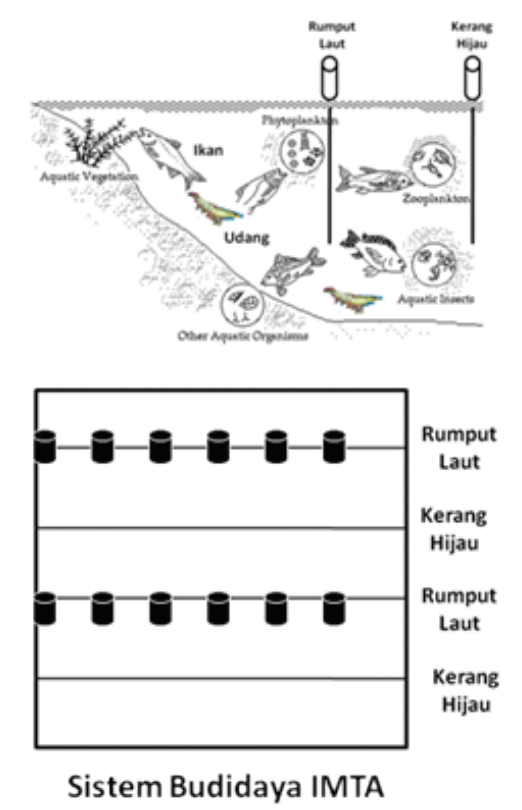

Gambar 3. Desain kolam penelitian dan pola tanam komoditas perikanan budidaya penelitian model budidaya perikanan terintegrasi multi tropik atau "Integrated Multi Tropical Aquaculture (IMTA)" 


\subsection{Kualitas Tanah}

Sebelum kolam digunakan, kolam diolah dan tanahnya dianalisa untuk mengetahui $\mathrm{pH}$, suhu tanah dan potensial redoksnya seperti terlihat pada Tabel 1. Parameter ini digunakan untuk mengetahui layak tidaknya kolam digunakan untuk kegiatan budidaya. Pengolahan kolam, selain dengan mengangkat lumpur dan mengeringkan, juga dilakukan pembebas hamaan dengan menggunakan Saponin. Pemupukan dengan menggunakan pupuk kandang juga dilakukan untuk meningkatkan kesuburan perairan yang diperlukan agar kolam secara alami dapat menyediakan pakannya. Untuk mengairi kolam, dilakukan pemasangan saluran pemasukan dan pembuangan air. Selengkapanya kegiatan pengolahan kolam dan pemasangan saluran terlihat pada Gambar 4.

Berdasarkan hasil analisa tanah pada Tabel 1 terlihat bahwa kondisi tanah kolam pemeliharaan bersifat sedikit asam sampai dengan normal dengan kisaran nilai pH antara 6-7. Sedangkan nilai potensial redoksnya
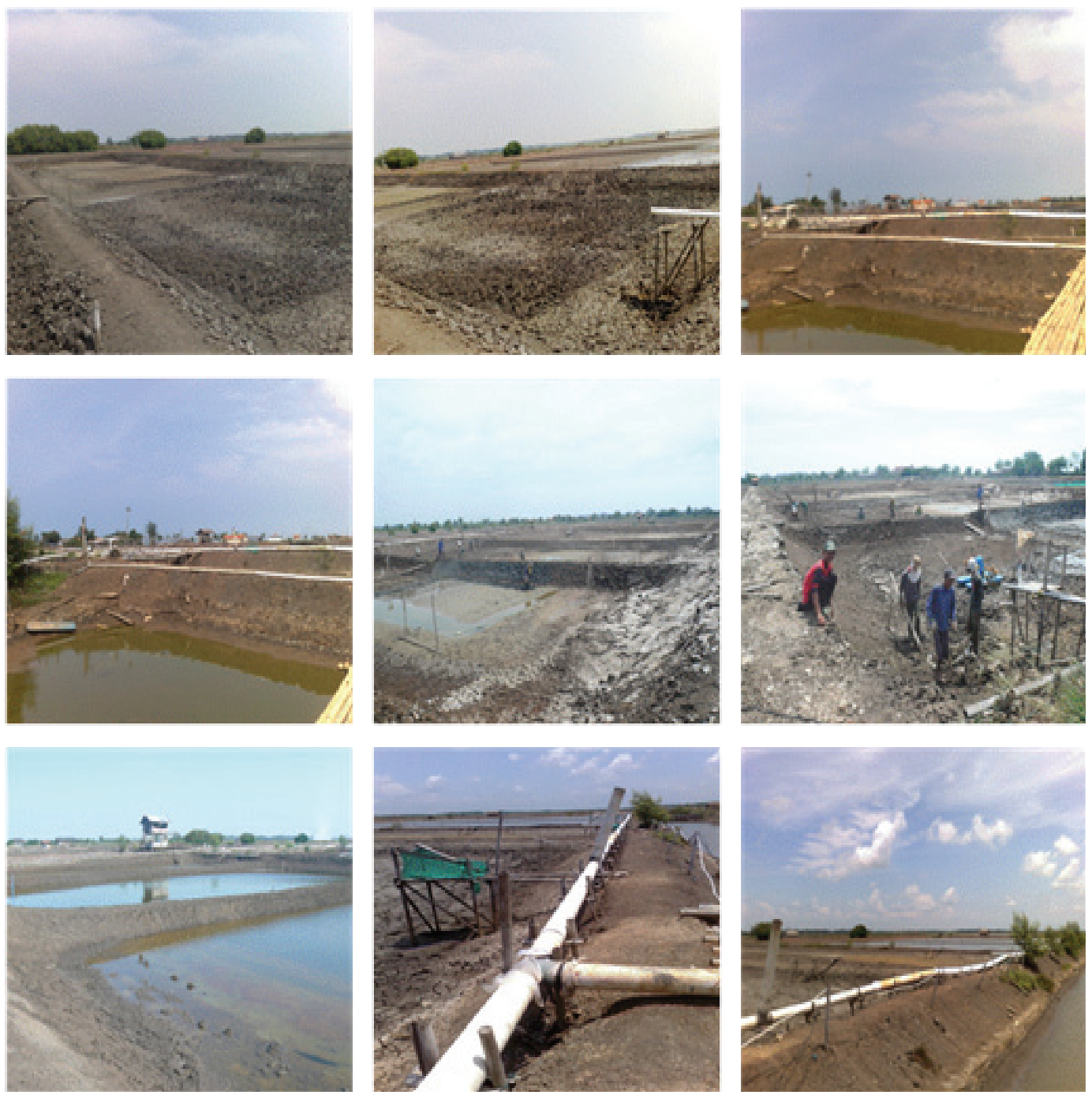

Gambar 4. Pengolahan kolam dan pemasangan saluran pengairan. 
Tabel 1. Parameter Kimia Tanah Kolam Pemeliharaan

\begin{tabular}{|c|c|c|c|c|c|c|c|c|}
\hline \multirow[b]{2}{*}{ No. } & \multirow[b]{2}{*}{ Kolam } & \multicolumn{2}{|c|}{ Inlet } & \multicolumn{2}{|c|}{ Tengah } & \multicolumn{2}{|c|}{ Outlet } & \multirow{2}{*}{$\begin{array}{c}\text { Suhu } \\
\text { Tanah } \\
\left({ }^{\circ} \mathrm{C}\right)\end{array}$} \\
\hline & & $\mathrm{pH}$ & $\begin{array}{c}\text { Potensial } \\
\text { Redoks } \\
(\mathrm{mV})\end{array}$ & $\mathrm{pH}$ & $\begin{array}{l}\text { Potensial } \\
\text { Redoks } \\
\text { (mV) }\end{array}$ & $\mathrm{pH}$ & $\begin{array}{c}\text { Potensial } \\
\text { Redoks } \\
(\mathrm{mV})\end{array}$ & \\
\hline 1. & Kolam 1-4 & 7,55 & $+4,3$ & 6,63 & $+28,4$ & 7,18 & $-2,1$ & 16,8 \\
\hline 2. & Kolam 5-8 & 7,32 & $-9,9$ & 7,04 & $+4,5$ & 6,78 & $+15,4$ & 13,2 \\
\hline 3. & Kolam 9-12 & 6,86 & $+31,4$ & 6,87 & +13.1 & - & - & 16,9 \\
\hline
\end{tabular}

rata-rata positif dan hanya disekitar inlet dan oulet saja yang bersifat negative. Artinya dari segi kelayakan, kolam pemeliharaan, kondisi kolam masih dalam taraf konservatif untuk dapat digunakan dalam kegiatan budidaya. Untuk selanjutnya, kolam akan dilakukan pengisian air dan pemasukan komoditas budidaya sesuai dengan rencana kegiatan pemeliharaan.

\subsection{Kondisi Lingkungan Perairan}

Berdasarkan hasil analisa dan evaluasi terhadap data fisik kualitas lingkungan perairan (suhu, salinitas, DO, kekeruhan, $\mathrm{pH}$, konduktivitas) dan parameter kimia (ammonia, nitrat, nitrit, fosfat, sulfida dan besi) dari 12 kolam model budidaya, terdapat berbagai variasi yang cukup menarik untuk dicermati. Profil kondisi fisik lingkungan perairan rata-rata terlihat pada Tabel 2 . Secara umum kondisi fisik lingkungan perairan untuk seluruh model kolam dalam keadaan normal dan layak untuk mendukung kehidupan biota yang dibudidayakan. Namun perbedaan yang cukup menarik terlihat pada model kolam P-4 dimana suhu dan DO nya relatif tinggi sementara salinitas dan $\mathrm{pH}$ nya cukup rendah. Suhu dan DO yang tinggi di kolam P-4 diduga terjadi karena pada Kolam P-4 terdapat rumput laut dimana peningkatan suhu akibat penambahan pencahayaan dari senar matahari telah menyebabkan proses fotosintesi dari rumput laut yang menghasilkan DO meningkat, kondisi yang sama terlihat pada kolam P-3 dimana pada kolam tersebut juga terdapat rumput laut. Pada kolam P-4 nampaknya tingkat kekeruhan cukup tinggi, namun kadar TSS nya cukup rendah. Hal ini menunjukkan bahwa di kolam P-4, kekeruhan didominasi oleh chlorophyll-a dimanapada siang hari akan menambah kadar oksigen kedalam perairan melaui proses foto sintesis. Dari kondisi ini dapat disimpulkan bahwa keberadaan rumput laut di kolam P-4 dan P-3 telah membantu meningkatkan kualitas dan stabilitas perairan.

Ditinjau dari parameter kimia, kondisi kolam P-4 kadar ammonianya cukup rendah. Demikian halnya dengan kadar fosfat dan sulfidnya (Tabel 3). Kondisi yang sama terlihat pada kadar DIN (Dissolve Inorganic

Tabel 2 . Profil kondisi fisik lingkungan perairan rata-rata kolam pemeliharaan

\begin{tabular}{|c|c|c|c|c|c|c|c|}
\hline Perlakuan & Suhu ( C) & $\begin{array}{c}\text { Salinitas } \\
\text { (ppt) }\end{array}$ & pH & DO (ppm) & $\begin{array}{c}\text { Kekeruhan } \\
\text { (NTU) }\end{array}$ & $\begin{array}{c}\text { TSS } \\
(\mathrm{mg} / \mathrm{l})\end{array}$ & $\begin{array}{c}\mathrm{BOD}_{5} \\
\text { (mg/l) }\end{array}$ \\
\hline P-1 & 30.81 & 24.94 & 7.92 & 6.02 & 121.83 & 36.5 & 1.66 \\
\hline P-2 & 30.77 & 23.11 & 7.87 & 6.16 & 127.46 & 22.33 & 0.71 \\
\hline P-3 & 30.92 & 22.48 & 7.90 & 6.43 & 157.08 & 22.83 & 0.24 \\
\hline P-4 & 30.94 & 22.91 & 7.91 & 6.47 & 177.67 & 18 & 1.18 \\
\hline
\end{tabular}


Nitrogent $=$ Ammonia + nitrat + nitrit $)$ DIP (Dissolve Inorganic Phosphate) sulfide dan besi pada Gambar 4. Hal ini menunjukkan bahwa dari segi kimia kondisi kolam P-4 cukup baik dalam proses pendaur ulangan bahan-bahan organik baik yang berasal dari sisa pakan, buangan kotoran spesimen yang dibudidayakan maupun dari faktor luar yang masuk ke dalam kolam.

\subsection{Keragaan Pertumbuhan Komoditas Budidaya}

Untuk beberapa komoditas yang dipelihara dalam 12 kolam pemeliharaan dari 4 jenis model budidaya, komoditas udang hanya bertahan hidup selama 1-2 bulan dari 4 bulan masa pemeliharaan yang direncanakan. Kematian udang diduga disebabkan beberapa kemungkinan antara lain dikarenakan infeksi virus vibrio, dimakan ikan nila atau pengaruh rendahnya potensial redoks dari kolam pemeliharaan. Namun untuk 1 blok model kolam pemeliharaan, udang masih hidup sampai dengan 4 bulan masa pemeliharaan. Melihat fenomena ini, nampaknya ketiga faktor diatas perlu dicermati dan dievaluasi kebenarannya

Tabel 3 . Profil kondisi kimia lingkungan perairan rata-rata

\begin{tabular}{|c|c|c|c|c|c|c|}
\hline $\begin{array}{c}\text { Tambak } \\
\text { Perlakuan }\end{array}$ & $\begin{array}{c}\text { Amonia } \\
(\mathrm{ppm})\end{array}$ & $\begin{array}{c}\text { Nitrit } \\
(\mathrm{ppm})\end{array}$ & $\begin{array}{c}\text { Nitrat } \\
(\mathrm{ppm})\end{array}$ & $\begin{array}{c}\text { Phosphate } \\
\text { (ppm) }\end{array}$ & $\begin{array}{c}\text { Sulfide } \\
(\mathrm{ppm})\end{array}$ & Iron (ppm) \\
\hline P-1 & 0.097 & 0.008 & 1.350 & 0.835 & 0.040 & 0.237 \\
\hline P-2 & 0.093 & 0.068 & 1.517 & 0.283 & 0.063 & 0.238 \\
\hline P-3 & 0.190 & 0.123 & 1.367 & 0.375 & 0.050 & 0.360 \\
\hline P-4 & 0.088 & 0.049 & 1.667 & 0.142 & 0.040 & 0.252 \\
\hline
\end{tabular}

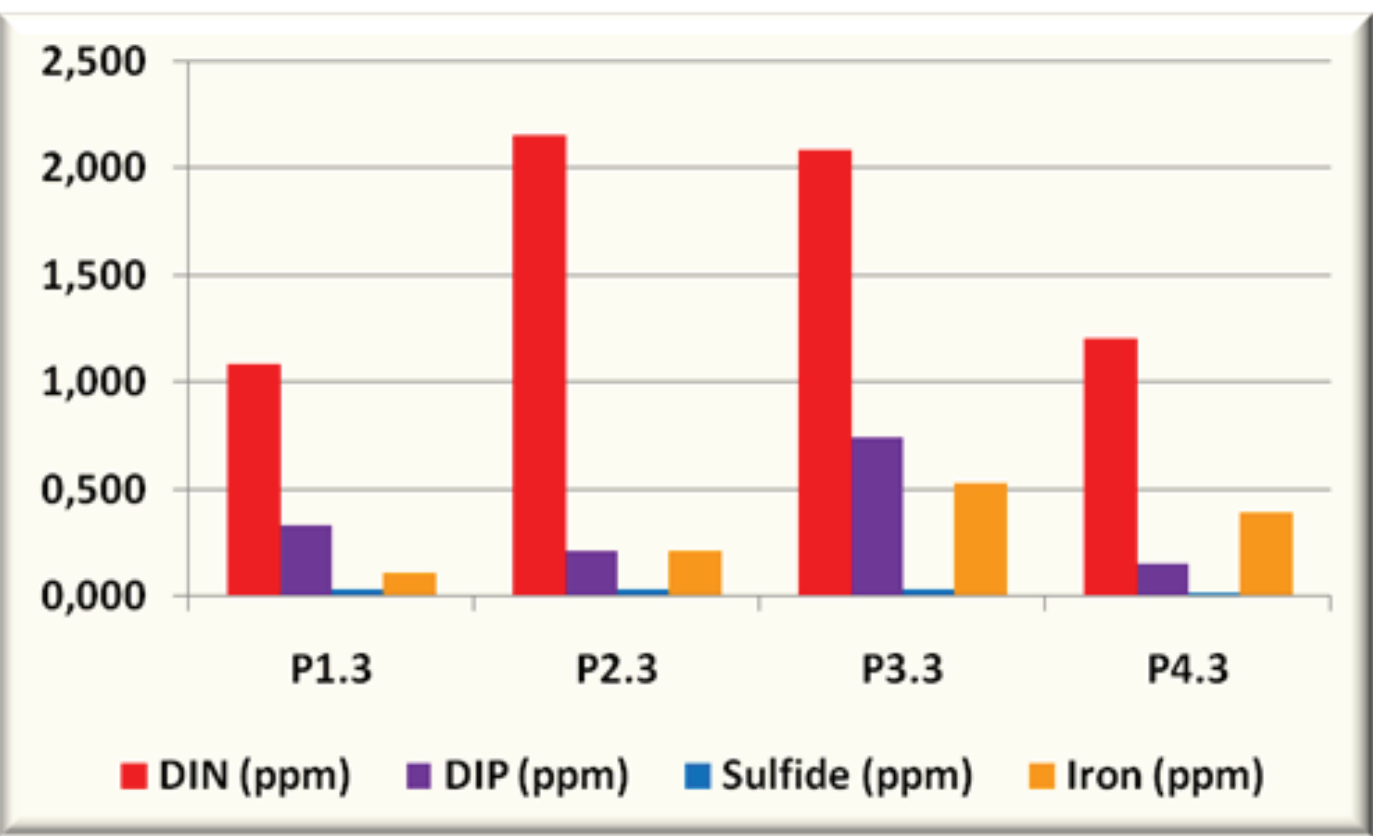

Gambar 4 . Kadar DIN (Dissolve Inorganic Nitrogent), DIP (Dissolve Inorganic Phosphate), sulfide dan besi. 
agar pemanfaatan kolam yang demikian dapat diarahkan sesuai dengan komoditas yang cocok dan dapat beradaptasi dengan kondisi lingkungan tersebut. Dari hasil pengamatan, ternyata ikan nila dapat tumbuh dan berkembang dengan baik dalam kondisi tanah berpotensial redoks yang rendah. Kedepan nampaknya untuk tambak atau kolam-kolam marjinal dan terbengkalai, dapat dimanfaatkan untuk pengembangan ikan nila. Untuk mengembangkan komoditas ikan nila di lahan tambak secara komersial, perlu dipikirkan bagaimana menekan biaya pakan yang saat ini harganya cukup tinggi dan meningkatkan harga jual ikan nila melalu pengembangan pola usaha kemitraan yang saling menguntungkan seluruh pelaku yang terlibat.

Dalam teknologi budidaya berwawasan lingkungan, proses pendaur ulangan atau pemanfaatan bahan organik sisa pakan dan buangan kotoran sangat penting dalam mengurangi limbah organik yang terbuang ke perairan dan tidak termanfaatkan. Dalam teknologi budidaya terintegrasi seluruh buangan bahan organik diharapkan dapat dikurangi bahkan dimanfaatkan untuk meningkatkan produktivitas lahan perairan marjinal dan menjaga stabilitas lingkungan perairan habitatnya. Hal ini sudah terbukti pada kolam $\mathrm{P}-4$ dimana spesimen yang dipeliharan secara terintegrasi telah memanfaatkan buangan limbah organik dalam perairan dimana bahan organik sisa pakan dan kotoran dari ikan dan udang dapat larutan inorganiknya dimanfaatkan untuk pertumbuahan rumput laut sebagai pupuk dan limbah organiknya dimanfaatkan kerang. Keberadaan rumput laut juga telah menambah kadar oksigen di siang hari. Demikian halnya dengan limbah organik yang dimanfaatkan kerang selain menjadikan kolam lebih jernih juga produktivitas kolam dapat meningkat dengan adanya tambahan pendapatan dari kerang. Hal ini ditunjukkan pada Gambar 5 dan 6.

\section{KESIMPULAN}

Teknologi budidaya perikanan terintegrasi multi tropik IMTA (Integrated Multi Tropic Aquaculture) dengan menggunakan ikan nila, udang, rumput laut dan kerang yang dipelihara dalam satu kolam telah menunjukkan produktivitas yang tinggi dan stabilitas lingkungan yang cukup baik dibandingkan dengan yang monokultur. Demikian halnya denga budidaya yang sejenis walau tidak menggunakan kerang, telah memberikan produktivitas dan kualitas air yang lebih baik. Walaupun demikian kondisi dan kualits tanah juga berpengaruh besar terhadap keberhasilan budidaya terutama untuk komoditas udang windu yang hidup di dasar. Nilai potensial redox yang negatif dapat menjadi tanda buruknya

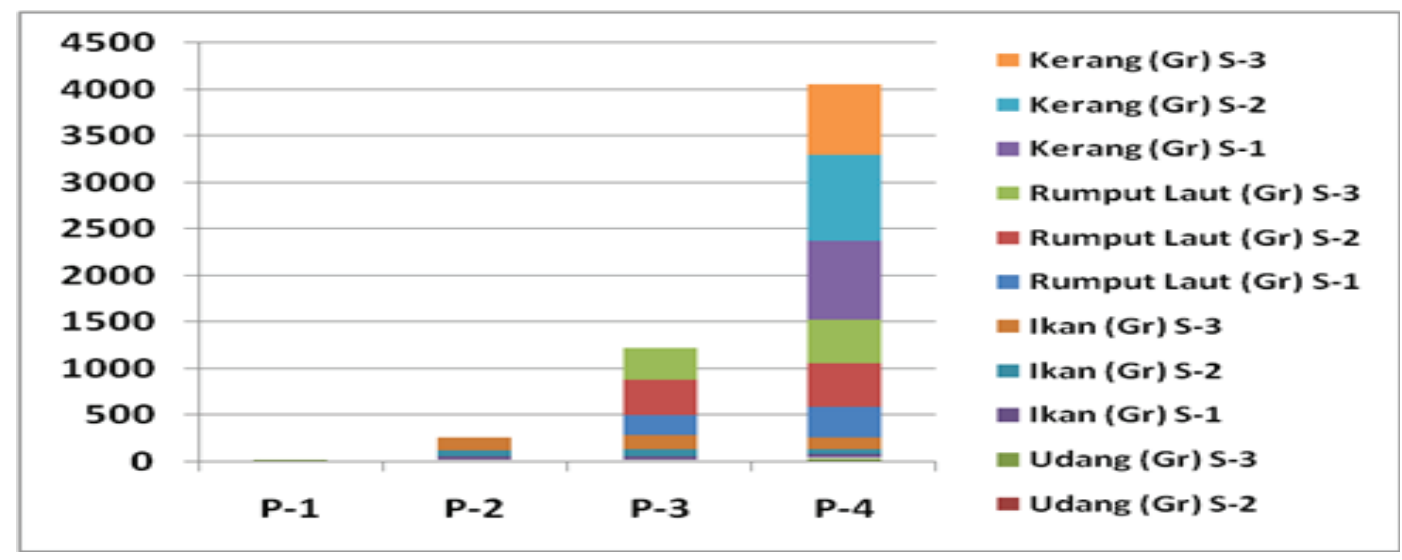

Gambar 5. Produktivitas model-model kolam budidaya 

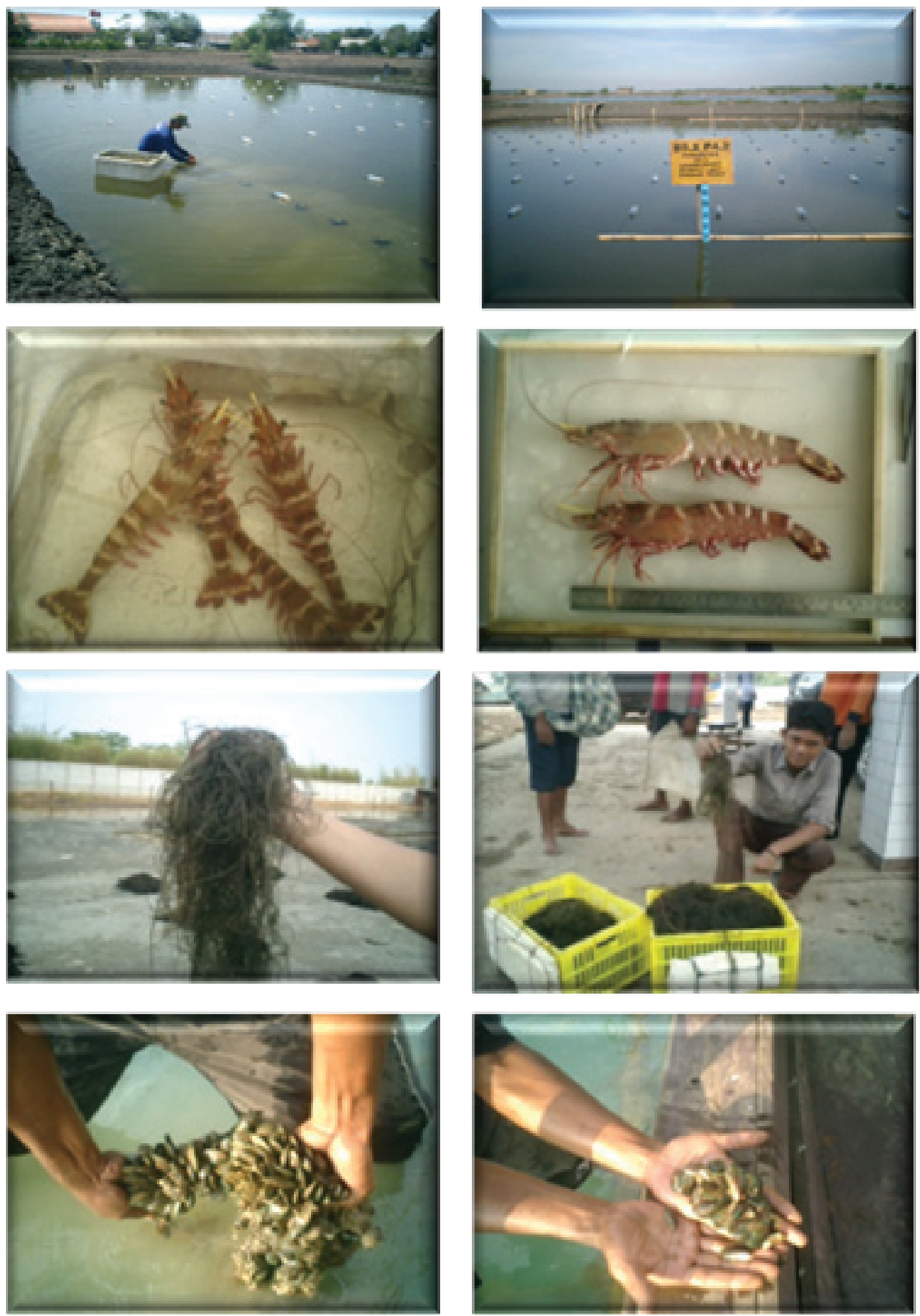

Gambar 6. Kolam pemeliharaan, rumput laut, ikan nila, udang dan kerang 
kualitas tanah untuk budidaya dan perlu di rehabilitasi. Untuk tanah seperti ini nampaknya ikan nila dan rumput laut menjadi alternatif komoditas yang cukup baik untuk dikembangkan, karena pertumbuhannya tidak terganggu.

Masalah lain yang perlu dicermati dalam budidaya dengan teknologi IMTA ini, adalah pengendalian penyakit. Untuk menghindarinya, sumber air hendaknya dapat bebas dari penyakit agar tidak menyebar. Kualitas air yang stabil dalam kolam apabila terkontaminasi air yang mengandung penyakit menjadi terganggu. Demikian halnya dalam menjaga stabilitas lingkungan perairan secara fisik terutama kadar salinitas dimana variasi hariannya cukup fluktuatif. Untuk suhu, fluktuasi hariannya menunjukkan pola yang sama dimana rendah di pagi dan malam hari serta tinggi di siang dan sore hari. Kondisi ini nampaknya telah dapat diadaptasi oleh organisma yang dipelihara. Sedangkan salinitas, walaupun dapat dikendalikan, fluktuasi hariannya sulit dikontrol terutama berhubungan dengan musim, dimana musim hujan salinitas bisa drop dan dimusim kemarau meningkat.

Kedepan pengembangan teknologi budidaya terintegrasi ikan nila unggul perlu dicarikan komoditas yang sifatnya tidak kenibal, sehingga waktu penebarannya bisa bersamaan. Beberapa alternatif komoditas dan desain kolam pemeliharaan untuk komoditas yang kompetitif dapat dikembangkan. Secara ekologis komoditas ikan nila sangat cocok dipadukan dengan udang windu, karena air kolam pemeliharaan ikan nila dapat menghambat pertumbuhan virus vibrio yang sering menyerang udang. Untuk beberapa kolam yang kondisi tanahnya cukup baik, udang windu dapat berkembang dengan baik. Sedangkan ikan nila dapat berkembang dalam kondisi kolam yang marjinal. Namun untuk dikembangkan dalam salinitas tinggi perlu dilakukan adaptasi. Untuk itu pengembangan ikan nila salin yang dapat hidup pada salinitas tinggi sangat dihapakan untuk mengisi kolam-kolam tambak marjinal dan belum termanfaatkan. Selain itu ikan nila dapat dijadikan sebagai salah satu komoditas alternatif terbaik untuk dikembangkan dilahan marjinal yang kondisi tanahnya kurang baik terutama untuk udang.

Hasil-hasil kegiatan telah menunjukkan bahwa Prototipe model budidaya terintegrasi lebih produktif dan stabil secara ekologis ditinjau dari kondisi lingkungan perairan. Protipe model budidaya ini meberikan tambahan produk tidak hanya dari komoditas utama yang menjadi target usaha budidaya seperti udang atau ikan nila, tetapi dari komoditas pendukungnya seperti rumput laut dan kerang. Hasil kegiatan juga telah menunjukkan bahwa ikan nila dapat bertahan hidup pada lahan tambak marjinal dimana komoditas udang tidak dapat tahan hidup lebih dari 2 bulan. Hasil ini menunjukkan bahwa ikan nila dapat dijadikan sebagai komoditas unggulan alternative selain udang yang dapat dikembangkan dilahan marjinal tambak di kawasan pesisir yang kualitas lingkungannya kurang baik.

Ditinjau dari stabilitas lingkungan perairan, model budidaya terintegrasi multi tropik dengan komoditas yang dipelihara ikan nila, udang, rumput laut dan kerang menunjukkan kualitas lingkungan perairan yang cukup prima dimana konsentrasi ammonia, nitrat dan partikel tersuspensinya cukup rendah dibandingkan dengan model kolam yang hanya menggunakan komoditas udang atau campuran udang dan nila. Kondisi ini menunjukkan bahwa proses bioresycle system untuk mengurangi limbah buangan atau sisa dari komoditas yang satu dimanfaatkan oleh komoditas yang lain. Limbah organik sisa pakan dan kotoran dari ikan nila dan udang telah dimanfaatkan kerang dan limbah inorganiknya dimanfaatkan rumput laut untuk pertumbuhan. Dalam model kolam budidaya terintegrasi ini, produktivitas menjadi meningkat dan kondisi lingkungan perairan tetap stabil. Kedepan model-model usaha budidaya perikanan secara terintegrasi berwawasan lingkungan 
berbasis bioresycle system dan zero waste emition dengan menggunakan berbagai komoditas perikanan bernilai ekonomis tinggi sangat prospektif untuk dikembangkan terutama dikaitkan dengan upaya menjaga keberlanjutan sumberdaya (sustainability) alam dan lingkungan yang saat ini tidak hanya menjadi issue nasional, tetapi sudah menjadi issue global. Issue ini sudah semestinya harus kita jaga dengan penuh tanggung jawab guna menjaga kesinambungan hidup manusia dalam menjamin ketersediaan pangan dan kemampuan sumberdaya alam untuk dapat tetap berproduksi.

\section{DAFTAR PUSTAKA}

1) Chopin T. 2006. Integrated multi-trophic aquaculture. What it is, and why you should care... and don't confuse it with polyculture. Northern Aquaculture, Vol. 12, No. 4, July/August 2006, pg. 4.

2) Neori A, Chopin T, Troell M, Buschmann $\mathrm{AH}$, Kraemer GP, Halling C, Shpigel $M$ and Yarish C. 2004. Integrated aquaculture: rationale, evolution and state of the art emphasizing seaweed biofiltration in modern mariculture. Aquaculture 231: 361-391.

3) Troell M, Halling C, Neori A, Chopin T, Buschmann AH, Kautsky N and Yarish $\mathrm{C}$. 2003. Integrated mariculture: asking the right questions. Aquaculture 226: 69-90.

4) Chopin T, Robinson S, Sawhney M, Bastarache S, Belyea E, Shea R, Armstrong W, Stewart and Fitzgerald P. 2004. The AquaNet integrated multitrophic aquaculture project: rationale of the project and development of kelp cultivation as the inorganic extractive component of the system. Bulletin of the Aquaculture Association of Canada. 104(3): 11-18.

5) Goldman JC, Tenore RK, Ryther HJ and Corwin N. 1974. Inorganic nitrogen removal in a combined tertiary treatment - marine aquaculture system: I. Removal efficiencies. Water Research 8: 45-54.

6) Ryther JH, Goldman JC, Gifford JE, Huguenin JE, Wing AS, Clarner JP, Williams LD andLapointe BE. 1975. Physical models of integrated waste recycling - marine polyculture systems. Aquaculture 5: 163-177.

7) Huguenin JH. 1976. An examination of problems and potentials for future large-scale intensive seaweed culture systems. Aquaculture 9: 313-342.

8) Neori A, Krom MD, Cohen $Y$ and Gordin H. 1989. Water quality conditions and particulate chlorophyll a of new intensive seawater fishpond in Eilat, Israel: daily and dial variations. Aquaculture 80: 6378.

9) Shpigel M and Fridman R. 1990. Propagation of the Manila clam Tapes semidecussatus in the effluent of marine aquaculture ponds in Eilat, Israel. Aquaculture 90: 113-122.

10) Shpigel $M$, Neori $A$, Popper DM and Gordin H. 1993a. A proposed model for "environmentally clean" landbased culture of fish, bivalves and seaweeds. Aquaculture 117: 115-128.

11) Shpigel M, Lee J, Soohoo $B$, Fridman $R$ and Gordin H. 1993b. The use of effluent water from fish ponds as a food source for the pacific oyster Crassostrea gigas Tunberg. Aquaculture \& Fisheries Management 24: 529-543. 